\title{
MT DoE/EPSCoR Planning Grant annual technical Progress Report
}

\author{
DE-FG02-91ER75681 \\ In support of Proposed Amendment No. A001 for Renewal \\ and award of $\$ 500,000.00$ for \\ DOE No. 92018 "Graduate Traineeship Grant."
}

\section{August 31, 1982}

\author{
Prepared by: \\ Jerry J. Bromenshenk, Ph.D. \\ MT DOE/EPSCOR \\ MORE (Montana Organization for Research in Energy) \\ Program Director \\ Vadan L. Scruggs, M.S., J.D. \\ MORE Research Specialist \\ MORE Office \\ HS 100 \\ The University of Montana \\ Missoula, MT 59812.1002 \\ DISCLAIMER
}

This report was prepared as an account of work sponsored by an agency of the United States Government. Neither the United States Government nor any agencly thereof, nor any of their employees, makes any warranty, express or implied, or assumes any legal liability or responsibility for the accuracy, completerness, or usefulness of any information, apparatus, product, or process disclosed, or represents that its use would not infringe privately owned rights. Reference herein to any specific commercial product, process, or service by trade name, trademark, ence herein to any specilte comerist nocessarily constitute or imply its endorsernent, recom. mentation, of favoring by the United States Government or any agency thereof. The views and opinions of authors expressed herein do not necessarily state or reflect those of the United States Government or any agency thereof.
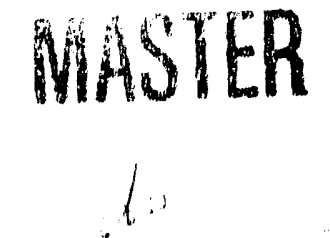


\section{EXECUTIVE SUMMAFY}

The Montana DOE/EPSCOR planning process has made significant changes in the state of Montana. This is exemplified by notification from the Departmerit of Energy's Experimental Program to Stimulate Competitive Research (DOE/EPSCOR) recommendation to fund Montana's 1992 graduate traineeship grant proposal in the amount of $\$ 500,000$. This is a new award to Montana. DOE traineeship reviewers recognized that our planning grant enabled us to develop linkages and build the foundation for a competitive energy-related research and traineeship program in Montana. During the planning, we identified three major focus areas: Energy Resource Base, Energy Production, and Environmental Effects. For each focus area, we detailed specific problem areas that the trainees nay research. We also created MORE, a consortium of industrial affiliates, state organizations, the Montana University System (MUS), tribal colleges, and DOE national laboratories. MORE and our state-wide Research and Education Workshop improved and solidified working relationships. We received numerous letters of support. DOE reviewers endorsed our traineeship application process. They praised the linkage of each traineeship with a faculty advisor, and the preference for teams of faculty members and two or more students. "Particularly commendable" were our programs to involve Native American educators and the "leveraging effect" of this on the human resources in the state. Finally, the DOE reviewers indicated that cost-sharing via support of Native Americans was creative and positive.

From Septernber 30, 1991 through August 31, 1992 we accomplished most of the tasks and met all of the milestones outlined in our original proposal. MCRE coordinators held frequent (often weekly) planning meetings at each of the six campuses of the Moritana university system. Dr. Bromenshenk and Mr. Scruggs traveled extensively across the state, visiting each campus to present overviews of the program and its goals, recruit participants (faculty, students, administrators), and interview state and federal agency personnel. Mr. Scruggs and three graduate students orchestrated development, mailing, receipt and processing of an extensive questionnaire distributed to faculty and administrators throughout the university system as well as to commurrity, private, and tribal colleges. The questionnaire also was sent to administrators and professional scientists in state and federal agencies and in the business sector.

The results from this survey helped define the agenda for the state-wide Workshop on Research and Education held in May in Helena, Montana. The Montana DOE and the EPA/EPSCOR committees jointly houted this workshop. Participants included representatives from the K-18 public and private educational systems, government and private research organizations local, state, and federal agencies, private industry, the state legislature, and the public. Other attendees included the South Dakota DOE/EPSCOR program director, representatives from DOE laboratories including the Idaho National Engineering Laboratory in Idaho, MSE, Inc., in Montana, and Associated Western Universities, Inc. (AWU) from Utah. Additional DOE related-laboratories and programs assisted us in the preparation for the conference. These included Battelle 
Pacific Northwest Laboratories and the Northwest Organization for Research Colleges and Universities (WORCUS).

The workshop generated a commitment by all participants to continue to meet regularly. Regular meetings will provide interested parties (from the private and public sector as well as academia) to communicate more easily and economically. These meetings will also enable the state to better pool scarce financial and other resources, disseminated information about educational programs and research opportunities, and simplify official "paper-trails". Workshop participants also advocated quarterly meeting by key individuals from academia, the private sector, public interest groups, government agencies, and the legislature. In addition, the participants concluded that the state-wide planning meeting should become an annual event. Participants suggested that an annual Montana Research and Education Workshop be held just before or after the State's Montana Academy of Science (MAS) meetings. EPSCOR researchers and trainees could present posters and papers at MAS. We will encourage participation by others (laboratory, agency, private) conducting energy-related research and education programs.

In addition to the focus areas identified in our traineeship proposal, the workshop identified the following priorities:

- Information Technology Linkages to Improve Communications between University, College, Education, Industry, Legislature, and Agency Personnel.

Educationai Programs that Teach Creative Thinking Skills/Data Arialysis.

- Ecological Monitoring to Address Biodiversity and Changes at Landscape, Regional, and Global scales.

- Ecosystem Festoration and Management (Bioremediation and Reclamation of Disturbed Lands).

- Materials Research as Applied to Alternative Energy.

- Improved thie Competitiveness of Montana (Extractive) Industries.

- Create an (MUS) energy/environment information administrator (new position) for education and research programs and place a MUS/State Agency representative in Washington, D.C.

Currently, we are organizing site visits to DOE laboratories in Washington and Idaho. We are preparing our five-year program plan, to be submitted to Donna Prokop by the end of September. We opened discussions with Research Vice-Presidents and state DOE/EPSCOR coordinators in Wyoming, North Dakiota, and South Dakota regarding 
regional capabilities, research, and needs. From September 30, 1992 to January 15, 1993 we will refine energy-research and education plans for Montana, and possibly the region. We will hold additional public workshops (across the state). We anticipate that we will be able to develop and deliver a highly competitive proposal to the anticipated FY 1593 DOE/EPSCOR merit-based research competition to be announced this fall.

\section{INTRODUCTION}

The following technical progress report is subrnitted as requested by the proposed amendment A001 which adds new traineeship funds to our initial planning grant and which extends the budget and project periods through September 24, 1994. We anticipate carrying-over an estimated $\$ 25,000$ of the initial planning grant funds. In July, we requested (before we were informed of the success of our traineeship grant proposal) a 90 day no-cost extension as recommended by Donna Prokop, DOE/EPSCOR program officer. We have a pressing need to hold several meetings and extensive travel to refine our five-year plan. This involves the conduct of some remaining public hearings and additional planning meetings (some of which will be in other states in the region) to orchestrate the Montana response to the anticipated DOE request for research proposals due by rnid-January, 1993. We emphasize that this technical progress report is not the Montana five-year plan nor is it in lieu of the report that we intend to provide by the end of Septernber, 1992, to Donna Prokop, the DOE/EPSCoR program officer.

\section{RATIONALE}

Energy resources have played a major role in Montana's history and will continue to do so. Montana's estimated coal reserves of 120 billion tons are greater than those of any other state. Montana ranks fifth in the ten-state northwest region in crude oil reserves and fourth in natural gas reserves. Energy resources continue to be a major contributor to Montana's economy. It goes without saying that Montana's energy resources have strategic irnportance to the state and the nation. However, Montana has a legacy of resiource exploitation and environmental degradation. For example, the nation's largest (squaremiles) EPA superfund site is in Montana. Our vision is that Montana can develop the technology, human resources, and political attitudes to prevent history from repeating itself.

Although Montana's natural resources are obviously important with respect to energy, Montana's most essential resource is the intellectual capacities of its population. In spite of a sparse population and problems associated with small schools and geographical isolation, Montana has the fourth highesi high school graduation rate in the nation and the third highest SAT scores. Lamentably, Montana's Native Americans have only a $50 \%$ graduation rate. In response, Montana has taken a leadership role in via organizations such as the American Indian Research Opportunities (AlRO) program. 
We recognize that research and the education of students are inseparable and vital to the people and the economic health of the state. For these reasons, the Governor, state officials, university administrators and faculty, business managers, professional staff, members of the science and technology alliance, and the public have been involved in a wide array of planning and implementation strategies to improve the state's research competitiveness, its educational programs and curricula. in addition to the DOE/EPSCOR activities, other key ingredients of Montana's strategic science plan are the establishment and funding of the Montana Science and Technology Alliance whose role, in part, is to ao'vise and provide financial assistance (by matching funds) to various science and technology activities, including the Montana EPSCOR programs (DOE, EPA, NSF, and possibly NASA, NIH, DOD, and USDA). The Montana Science and Technology Alliance (MSTA) recently established six focus groups to develop detailed strategies for organizing, prioritizing, and funding key fields of scientific research and technology.

Shortly after receipt of our planning grant, Montana EPSCOR coordinators (NSF, NASA, DOE, EPA, and NIH) recognized a need to re-organize the state-wide coordination of the EPSCOR programs as detailed in the Figure on the next page. Under this structure, which was finalized in April, 1992, the Executive Associate Commission of Higher Education, Dr. David Toppen, acts as the state-wide multi-agency EPSCoR coordinator in cooperation with the Research Vice-Presidents at the three research units of the university. The Research Vice.Presidents constitute the Montana University System Executive Committee. They provide guidance and direction to each of the EPSCOR program directors, who are located at the three major research units of the Montana University systern.

The Montana Technology and Science Alliance (MSTA), as a sub-division of the Montana Department of Commerce, works closely with the governor, private industries, and the university system. MSTA puts together legislative funding packages to support EPSCOR activities. It also has launched a several million dollar funding drive aimed at the private sector and other possible funding sources. Montana's governor, Stan Stevens, charged MSTA with developing a state-wide science plan. To accomplish this goal, MSTA established six focus committees. The deliberations of the Basic Science Focus group and of the Energy focus group provided considerable input to the Montana DOE/EPSCOR planning process.

To facilitate communication with the focus groups and the state's science plan, Dr. Bromenshenk, MT DOE/EPSPCoR program director was appointed by the governor to the Basic Science Focus group and was invited to participate in the meetings of the Energy Research Focus group. The Basic Science group included all of the Montana EPSC JR program directors (NSF, NASA, EPA, NIH). Key individuals from the private sector made up most of the Energy Focus group, chaired by John Murphy, Manager, Industrial Services, Montana Power. These members represented fossil fuels and mining industries, agri-business (incluoing alcohol fuels), alternative energy technologies, and conservation interests. The mission of the Energy focus group was to explore ways in 


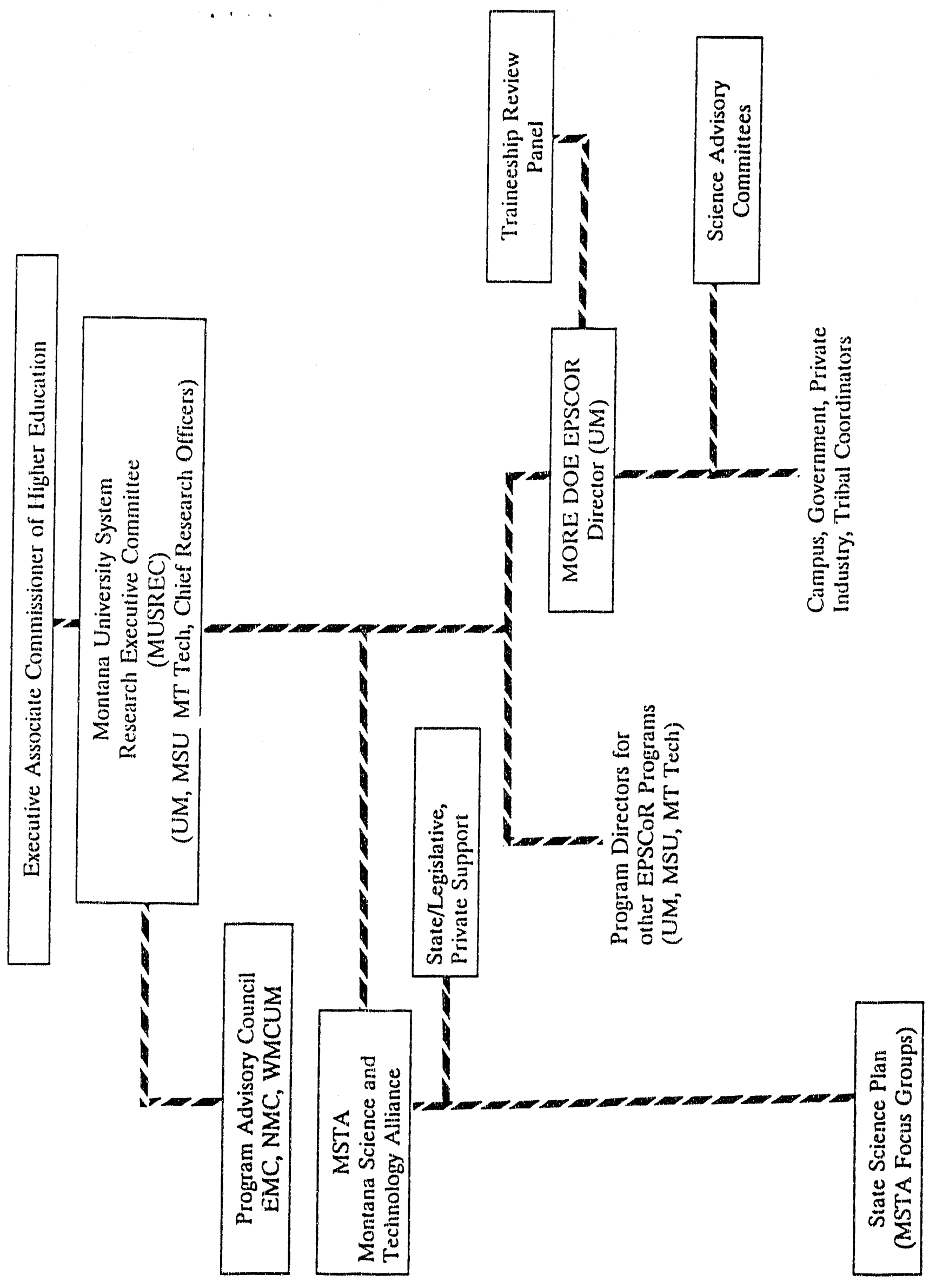


which science and technology might be applied to solve energy issues with the end result of safely developing and adding value to Montana's energy resources while guaranteeing efficient utilization.

Prior to the first meeting (in January, 1992) of the Energy focus group, investigators at each university unit had formed DOE/EPSCOR Science Advisory Committees for the purpose of developing a five-year strategic plan for Montana's Energy research and education. These committees constituted the core of a new organization - the Montana Organization for Research in Energy (MORE). Since the goals of MORE and the MSTA Energy focus group were similar, we agreed to share pertinent data and to have a representative from each group attend each meeting.

Preliminary reports were produced by the MSTA Focus groups in April, 1992. The final report, which will go to the governor and the 1993 legislature along with a request for budget support should be available by mid-October, 1992. This report will include materials derived from Montana's EPSCOR planning activities. Similarly, our final five-year plan for energy-related research and education will address issues raised by the six MSTA focus groups.

The DOE/EPSCOR and the MSTA Focus groups avoided debates over energy policy. The Environmental Quality Council (EQC) was directed by the Montana Legislature (HJR 31) to develop a state energy policy in cooperation with the Department of Natural Resources and Conservation, and the Montana Consumer Council. That effort currently is underway. EQC focused its efforts on inventories of existing energy-related legislation, development of a state energy policy goal statement, establishment of an ongoing state energy policy development within state government, development of an energy policy analysis protocol to evaluate and compare energy-related policy options, and paid special attention to involving the public in the HJR process. The EQC'S final policy may affect some of the issues raised by the DOE/EPSCOR, the MSTA energy-focus groups and other constituencies. Their report is due before the Montana legislature convenes in January, 1993.

Dr. Bromenshenk, UM, coordinated the Montana DOE/EPSCoR planning activities as well as preparation of the successful graduate traineeship proposal. He was assisted by Mr. Scruggs, a research specialist with a background in science, analytical laboratories, and environmental law. In addition, three UM graduate students helped with the surveys and data base construction.

Two co-investigators coordinated the DOE planning efforts at other Montana research institutions: Dr. Hugo Schmidt, Montana State University (MSU) and Dr. Daniel Bradley, Montana College of Mineral Sciences and Technology (MT Tech). Campus meetings were usually held bi-weekly. The state-wide Workshop on Research and Education was coordinated with the assistance of Dr. David Toppen, Deputy Commissioner of Higher Education, and Dr. Nina Klein, Montana EPA/EPSCoR 
coordinator. Additional planning activities were coordinated by Dr. Scott Mock, Western Montana College (WMC of UM); Dr. Martha Anne Dow, Northern Montana Ciollege (NMC); and Dr. Michael Dennis, Eastern Montana College (EMC). Mr. David Hollatz, EMC Clean-Coal Information Center; Ms. Carole Murray, Dean of Student Services, Blackfeet Comınunity College; Mr. John Murphy, Montana Power Company and Montana Science and Technology Energy-Focus Planning Chair; and Mr. Van Jamison, Energy Division, Montana Department of Natural Resources played key roles in the coordiriation of planning activities among the private sector, tribal colleges, and state agencies. The original MORE coordinators are listed in the next table. In May, 1992, Gene Ashby has replaced Robert Carrington as the Montana/MSE, Inc. coordinator, and in August, 1992, Dr. Reno Parker replaced Dr. Dow as the acting NMC DOE/EPSCOR coordinator.

The number of faculty participating on the Science Advisory Committees at each of the six campuses ranged from 5 to 15. The research vice-presidents provided release time to each of the three principal investigators. Together, along with time and effort provided by other agencies and individuals, the MT DOE/EPSCOR cost-share requirement for the entire planning grant budget should be easily met by the end of September, 1992; and we still have more meetings and activities planned for October through December, 1992, as we prepare our response to the anticipated FY 93 DOE/EPSCoR research program. It appears that we will exceed the original cost-share requirement (personnel time and waived indirect costs) of the planning grant.

The MORE planning process as outlined in our initial planning proposal included:

- Survey (via questionnaires and interviews) of individuals and facilities.

- Synthesis of Collected Information

- Database Construction

- Scientific Review

- Review by Executive Committee

- Conference (Montana Workshop on Research and Education)

- Proceedings

- Action Plan Review

- Scientific Review

- Review by Executive Committee

- Public Hearings

- Final Report 


\section{MORE COORDINATORS}

Dr. Jarry d. Bromarshank

Montana DOE'EPSCOA Program DIrector

Montana Organizauon for Research In Energy

Hoalth Sclences 110. The Unlversity of Menthna Mlssoula, MT 59812-1002

Tol: (406) 243-5648 FAX: (406) 243-4184

Bitnet: bl لjb@lewis.umt odu

Dr. Hugo Schmidt

Professor, Department of Physles

Collego of Lotters and Sclences, Montana State University Bozeman, MT 59717-0350

Tel: (406) 994-3614 FAX: (406) 994-4452 Bltnet: aphysicosomtsunix

Dr. Danked 1 Brasioy

Assoclato Dean, Petroloum Englneering Division Montana College of Mineral Sclence and Technoiogy Butte, Montana 59701

Tel: (406) 495-4254 FAX: (406) 496-4417

Dr. Martha Arno Dowe

Vlce-President for Academic Affairs Northern Montana College

P.O. Box 7751 , Havre, MT 59501

Tel: (406) 265-3700 FAX: (406) 265-3777

Dr. Watter Gullet

Interitn Assoclate Academic Vlce-President Eastern Montana College

1500 North 30th Streel, Bllings, MT 59101-0298

Tel: (406) 657-2238 FAX: (406) 657-2051

Dr. Kelin Parter

Dean of Faculty, Western Montana College

of The University of Montana

Dllon, MT 59725-3598

Tel: (406) 683-7261 FAX:(406) 683-7493

Cand Murtay

Dean of Student Services, Blisckfeet Community College

P.O. Box 55, Browning, MT 39417

Tel: (406) 338-7755 FAX: (406) 338\%-7808

Van Jamian

Administrator, Energy Divislon

Montina Department of

Natural Resources and Conservation

1520 E. Sixth Avenue, Helena, MT 59620

Tel: (406) 44.4-6754 Fax: (406) 444-6754

John E Murptry

Chalman, Sclence and Technology Alliance Enorgy Focus Group Manager, Industital Servlces

Montana Power Company

40 Ease Broactway, Butio, MT 59701

Tel: (406) 72J-5421 FAX: (406) 496-5099

Dr. Fobert A. Carringtion

Tochnlcal Program Manager

DOE Componant Dovalopment and Integratlon Facllity

P.O. BOx 1078 , Burin, MT 59702

Tal: (106) 494-7967 FAX: 494-7230 
Taking these items in order, we provide the following summary of activities. During the first two quarters of the project period, Dr. Bromenshenk, Mr. Scruggs, and three graduate students conducted an extensive review of ER activities in the state. The first stage of this process was identification of Montana researchers. A questionnaire was developed, compiled, and distributed in April. The questionnaire was designed to identify Montana's research personnel as well as research shortcomings, capabilities, and potential. The survey also solicited suggestions to improve state-wide communications, provide linkages arnong communities, and build a better infra-structure to support research and education.

The data gathering was accompanied by meetings with scientific advisors at each of the units of the Montana University system. These activities were intended to provide information and develop a database for grant proposal development and for the Montana Workshop on Research and Education held in May in Helena, Montana. The Workshop provided the cornerstone for Montana's five-year research and education plan.

During this same period, Dr. Bromenshenk and Mr. Scruggs conducted personal interviewed administrators and scientists at Montana universities and colleges, state agencies, and federal and private businesses. Additional interviews are scheduled for September through December, 1992.

Development of the survey tool was assisted by Dr. Allan Sillars, UM Department of Interpersonal Communications. His assistance and those of several other survey specialists negated the need to contract the services a survey specialist. Dr. Sillars conducts courses on survey techniques. In addition, construction of the data base and the survey tool was greatly enhanced by the participation of three UM M.S. graduate students. Each had nearly completed a Master's thesis. One in business administration, one in interpersonal communications, and one in computer science. The first two had extensive survey training and had utilized these techniques in their thesis activities. The third was a specialist in constructing customized data bases. Before being distributed, drafts of the survey tool were distributed to more than 40 of the DOE/EPSCOR advisors and the Executive Committee for comment and review.

A total of 561 questionnaires were mailed to Montana scientists and educators. Survey forms were returned from employees at community colleges, Montana university system colleges and universities, state and federal agencies, private interest groups, and businesses. Initial results of the survey tool were provided to all attendees at the Montana Workshop on Research and Education. The final results will be provided in our September, 1992 report to Donna Prokop, DOE/EPSCoR program officer. Selected findings and a preliminary summary are attached in Appendix $A$ of this technical report.

In our synthesis reports that we distributed for review, both to individuals and to the Workshop, we pointed out the following. The majority of the respondents believe that interest in science has substantially increased at their organizations during the last few 
years. Less than half believe that their work group is communicating well with other research organizations. A substantial number of respondents indicate that their organization (includes businesses) must invest significant resources for additional training for graduates from Montana's schools. An overwhelming number indicated that student traineeships and/or internships would significantly benefit Montana research. Well over half believed that Montana's university system provides nationally competitive preparation, but almost one-quarter challenge that view. Over half of the educators expressed interest in learning more about the education and training needs of businesses. Greater than sixty percent of all respondents believe that Montana state agencies should be actively engaged in research programs.

The Montana Workshop on Research and Education brought together individuals with a wide-array of backgrounds and interests. Objectives of the conference were:

- Provide a forum for information exchange between researchers, educators, agencies, and businesses within Montana.

- Identify research and educational resources within this state.

- Identify strengths and weaknesses regarding energy-related research and environmental programs within the state.

- Delineate infrastructure issues essential to implementing a comprehensive and workable research and education plan.

- Make recommendations that will be incorporated into a five-year research plan for the state of Montana.

Copies of Workshop Agenda and highlights of the results are included in Appendix B. The level of participation by state agencies such as the Department of Natural Resources and the Department of Commerce as well as participation by the tribal colleges was high and lead to the creation of important linkages and commitments to continued communications as well as forging working relationships that should lead to enhanced opportunities for cooperative research and education.

The workshop built upon three energy-research focus areas identified in our trairieeship proposal. The workshop added a focus or material science and under-scored the importance of research in support of Montana energy-laboratories and industries. The original focus areas were identified during the winter planning activities by more than 30 faculty at the university campuses.

The Montana DOE and the EPA/EPSCoR committees jointly hosted this workshop. Participants included representatives from the K-18 public and private educational systems, government and private research organizations, local, state, and federal 
agencies, private industry, the state legislature, and the public. Other attendees included the South Dakota DOE/EPSCoR program director, representatives from DOE laboratories including the Idaho National Engineering Laboratory in Idaho, MSE, Inc., in Butte, Montana, and Associated Western Universities, Inc. (AWU) from Utah. Additional DOE related-laboratories and programs aided in preparation for the conference. These included Battelle Pacific Northwest Laboratories and the Northwest Organization for Research Colleges and Universities (NORCUS).

The workshop generated a commitment by all participants to continue to meet regularly. Regular meetings will provide interested parties (from the private and public sector as well as academia) to communicate more easily and economically. Also, the state can better pool scarce financial and other resources. Educational programs and research opportunities can be more easily disseminated. Official "paper-trails" could be simplified. Workshop participants strongly advocated quarterly meeting by key individuals from academia, the private sector, public interest groups, and government agencies, and the legislature. In addition, the workshop participants concluded that the state-wide planning meeting should become an annual event. Participants suggested that the annual Montana Research and Education Workshop just before or after the State's Montana Academy of Science (MAS) meetings. EPSCOR researchers and trainees could present posters and papers at MAS. We would encourage participation by others (laboratory, agency, private) conducting energy-related research and education programs.

In addition to the focus areas identified in our traineeship proposal, the workshop identified the following priorities:

- Information Technology Linkages to Improve Communications between University, College, Industry, Education, Legislature, and Agency Personnel.

- Educational Programs that Teach Creative Thinking Skills/Data Analysis.

- Ecological Monitoring to Address Biodiversity and Changes at Landscape, Regional, and Global scales.

- Ecosystem Restoration and Management (Bioremediation and Reclamation of Disturbed Lands).

- Materials Research as Applied to Alternative Energy.

- Improved Competitiveness of Montana (Extractive) Industries.

- Set up a (MUS) energy/environment information administrator (new position) for education and research programs and place a MUS/State Agency representative in Washington, D.C. 
The tables on the next pages provide a summary of the priorities for research and educational development as identified by individual conference working groups. These tables also summarize resources and possible funding sources.

An important aspect of the Workshop was the Pre-conference for special interest group discussions. We were pleased to find that attendance at that session was as good as at the other sessions. In addition, many participants, such as the representatives from the three tribal colleges primarily came for these discussions.

In addition to the aforementioned activities, the DOE/EPSCOR coordinators and the science advisory committees at each campus spent a considerable amount of time during February and early March, 1992, in the development of our graduate traineeship proposal. Developing the proposal provided a sense of immediacy and provided a focus to the deliberations of each working group. The principal coordinators, Drs. Bromenshenk, Schmidt, Bradley, as well as the MSTA Energy focus group chair, John Murphy, met several times in Butte and Bozeman. Following subrnission of the traineeship proposal and prior to the Helena workshop. Dr. Bromenshenk visited each of the six Montana campuses to meet with and to interview administrators, faculty, and students.

Activities planned for September, 1992, include a site visit by representatives from each of the six university units and a representative of the tribal colleges to Battelle Pacitic Northwest Laboratories to discuss research and traineeship collaborations. A specific goal is to develop a more formalized agreement regarding working relationships with Hanford contractors and to make personal contacts among researchers and educators. A similar visit is planned for later in the year with the ldaho National Engineering Laboratory.

We also intend before the end of the month to finalize, distribute for review and comment, and then deliver a strategic plan to Donna Prokop. 'We are requesting authorization to carry over funds to support supplies, travel, and salaries for the DOE/EPSCOA program officer and research specialist. During the period of September 30,1992 , through January 15,1993 , we intend to refine the five-year plan, conduct public hearings, and coordinate development of the response to the anticipated 1993 DOE/EPSCOR request for proposals to realize the Montana DOE/EPSCOR plan and to fund collaborative research in energy-related science and engineering disciplines.

We conserved funds to bridge the time between the end of the original planning period and the time of the anticipated submission date for this anticipated request for research proposals which is the logical next step following the planning process. At the DOE/EPSCOR Workshop on DOE programs and initiatives, hosted by DOE in Washington, D.C. in May, 1982, Donna Prokop indicated that requesting a no-ccst extension for this purpose seemed to be a reasonable request. Montana was represented at this meeting by Drs. Bromenshenk (UM) and Schmidt (MSU). We were 


\begin{tabular}{|c|c|c|c|c|c|c|c|c|}
\hline 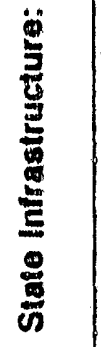 & 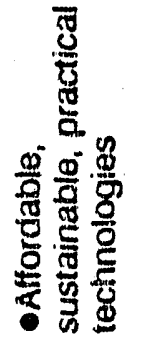 & 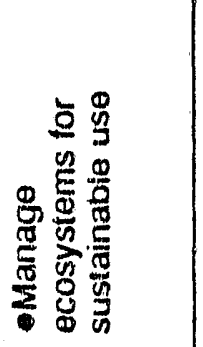 & 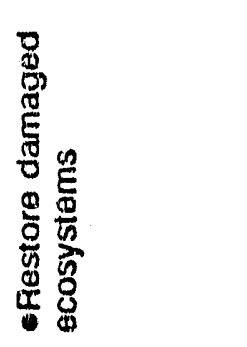 & 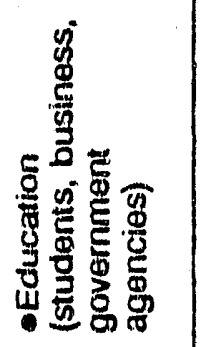 & & & & \\
\hline 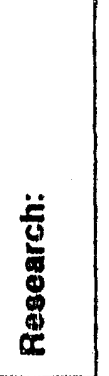 & 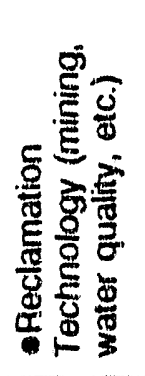 & 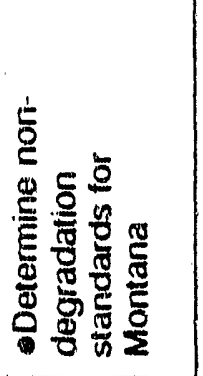 & 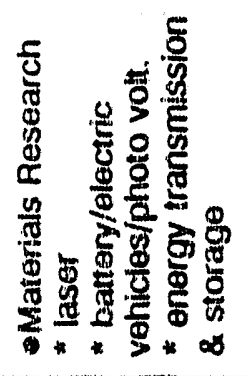 & 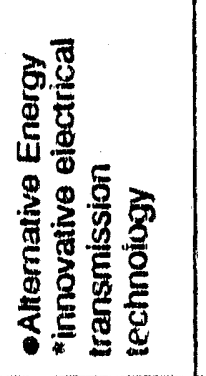 & 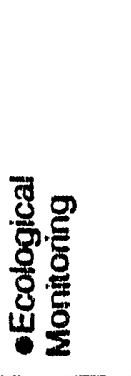 & 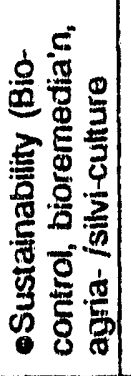 & 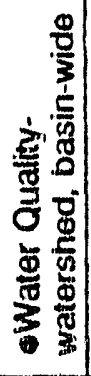 & 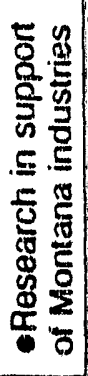 \\
\hline 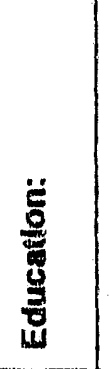 & 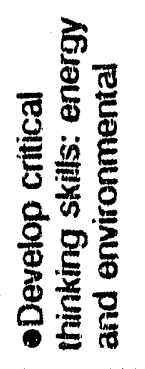 & 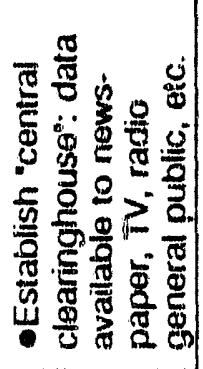 & 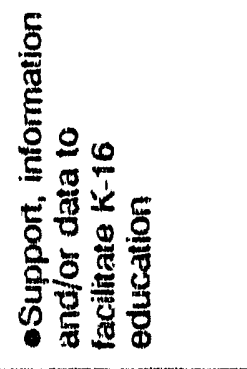 & & & & & \\
\hline 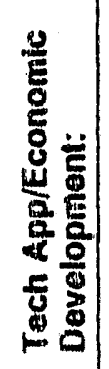 & 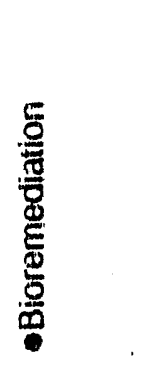 & 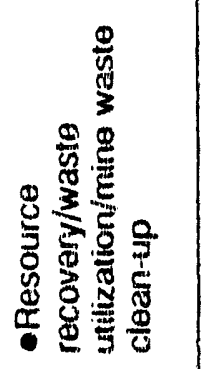 & 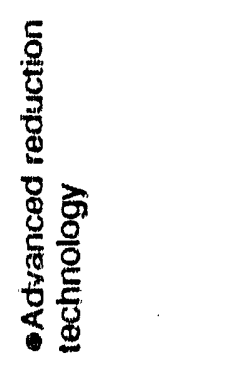 & 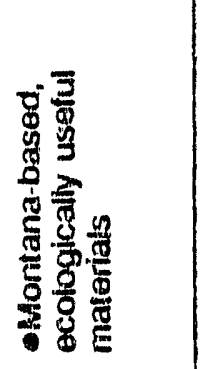 & 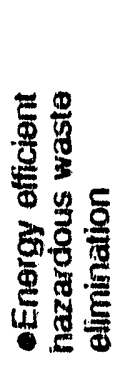 & 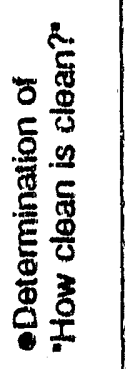 & & \\
\hline 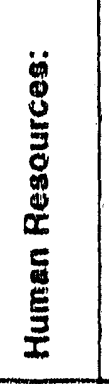 & 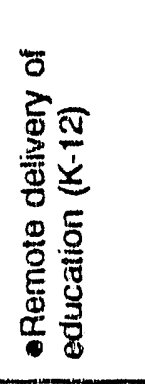 & 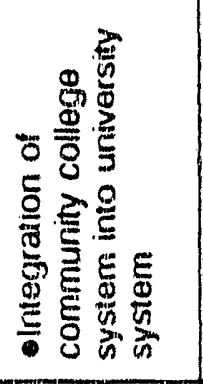 & 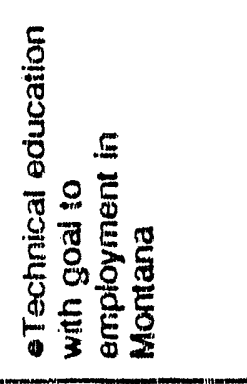 & 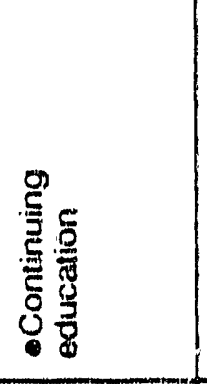 & 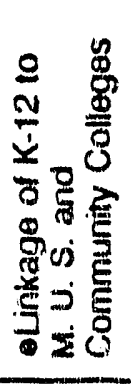 & & & \\
\hline 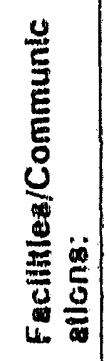 & 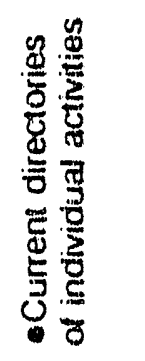 & 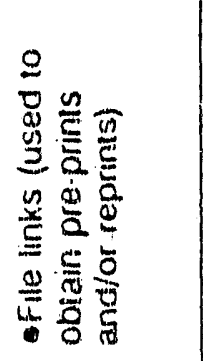 & 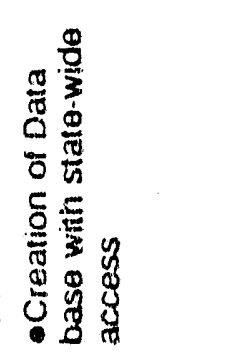 & 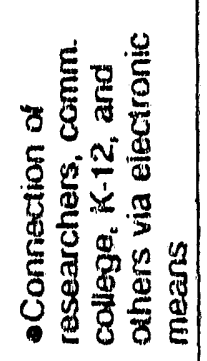 & & & & \\
\hline
\end{tabular}


$R=$ RESOURCE, \# = PRIORITY $(\# 1-6) ; F=$ POSSIBLE FUNDING SOURCE

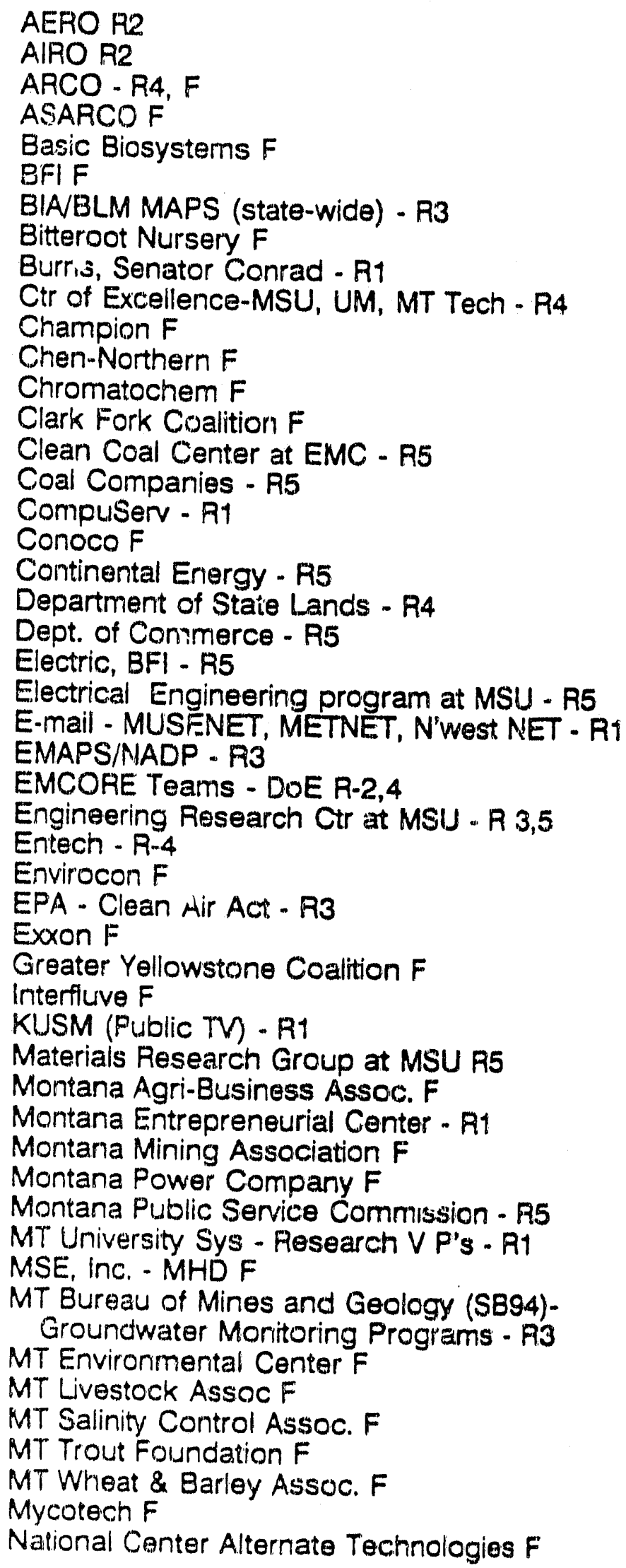


pleased that the Energy Division of the Montana Department of Natural Resources and Conservation sent (at their own expense) Mr. Paul Cartwright of the Energy Division.

We have delayed the public meetings to onable us to incorporate the findings of the MSTA focus groups in our five- $j:-:-j a n$. The final MSTA report has been delayed until mid-October from an original projected delivery date of August, 1992. The MSTA report must be finished within the next month or two, if it is to be presented to the Montana legislature when it meets in January, 1993. Similarly, the EQC energy-policy report is due before the legislature begiris its sessions. Both of these planning efforts are likely to produce issues and strategies t'nat will enhance and possibly change the direction of the MORE five-year plan.

Several realizations have emerged from our planning efforts. We need to reduce competitiveness and encourage cooperation among the universities and we reed to make some systemic changes in this state with respect to science, math, and engineering education. An important first step is the inkage of each traineeship with a faculty advisor and the preference for inter-university (and college) teams of faculty members and two or more students. Another important step is the involvement of the tribal colleges as partners in this enterprise, and the provision by the Montana University system of costsharing to support Native Americans and the setting-aside of some of the traineeships for tribal college instiuctors. This program has the potential for "leveraging" the human resources in the state.

We are excited about the potential that the traineeship award has for advancing these objectives. The notice of the recommendation for funding has generated considerable interest and excitement about the DOE/E:PSCOR program. Our challenge is to make this a quality prograrn that will become a model for other states. We are in total agreement with the DOE reviewers about need for external review of the traineeship proposals. Setting up the traineeship review panels is one of our first tasks. Widely advertising the traineeship program is another. Getting quality students into the program is the highest priority. 
APPENDIX A 
Beginning in the fall of 1991, The University of Montana began a study to assess the state's energy-related research capability and needs. The Department of Energy (DOE) provided the primary funding through a planning grant. Additional economic support and personnel time has been provided by other units of the university system, state and federal agencies as well as private industry. The primary objective of the study is to provide Montanans with a five (5) year plan that will enable them to be more competitive in securing energy-related research and educational grants.

The first stage of the planning process is the identification of Montana researchers. A questionnaire was developed and distributed in April. The questionnaire is designed to identify Montana's research personnel as well as research capabilities, shortcomings, and potential. The survey also solicits suggestions to improve state-wide communications, provide linkages among communities, and build a bettex infrastructure to support research and education.

The data gathering was accompanied by meetings with scientific advisors at each of the units of the Montana University system. These activities were intended to provide information for grant proposal development and for the Montana Workshop on Research and Education. The Workshop is intended to provide the cornerstone for Montana's five year research and education plan.

Following the Workshop, personal intervievs with selected individuals and public hearings will be utilized to solicit aditional input. The information that is obtained from these multiple sources will be utilized in developing the final sive year plan waich will be submitted to DOE in the fall of 1992.

The Montana Workshop on Research and Education will bring together individuals with a wide-array of backgrounds and interests. objectives of the conference are:

(1) to provide a forum for information exchange between researchers, educators, agencies, and businesses within Montana;

(2) to identify research and educational resources within this state;

(3) to identify both strengths and weaknesses regarding energy-related research and environmental programs within the state:

(4) to further identify infrastructure issues essential to implementing a cohesive and workable research and education plan:

(5) to make recommendations that will be incorporated into a five year research plan for the state of Montana. 


\section{Brecutive 8umany}

561 questionnaires were mailed in April, 1992 to Montana scientists and educators. At this time 131 survey forms have been returned (for a $23.4 \%$ return rate). Responses were received from employees at community colleges, colleges, universities, state and federal agencies, private interest groups and businesses.

A majority of the respondents believe that interest in research has significantly increased at their organizations during the last few years. Less than half of the respondents indicate that their work group is communicating well with other research organizations. Nearly one third are concerned that quantity of research output is valued more than quality. A similar number indicated discontent with the system at their organization for evaluating research productivity. Slightly more than one third are dissatisfied with the the manner in which they are notified of grant and contract opportunities. More than half do not consider "overhead" costs to be a serious hindrance to competing for research funds. Well over three fourths indicated that pay is lower at their organization than at peer organizations.

Researchers were asked to respond to a proposed list of suggestions for improving their research capability. Their top "picks" in descending order as follows: seed money, more research equipment, more technical staff, greater financial incentive, better reference sources, improved information networks, indirect cost recovery to the investigator, more research space, and more graduate students.

A substantial number of the respondents indicate that their organization (includes businesses) must invest significant resources for additional training for graduates of Montana's schools. But in response to a related question, over half of the respondents are satisfied with the preparation students receive in Montana's university system, while more ihan a third are dissatisfied. $\quad$ in overwhelming number indicate that student traineeships and/or internships would significantly benefit research. In the specific areas of engineering, math and science, well over half believe that Montana's university system provides nationally competitive preparation. However, almost one quarter of the respondents challenge that view.

Well over half of the aducators responding to the questionnaire expressed interest in learning more about the education/training needs of businesses. An equal number of educator's indicate that their schools do not have adequate laboratory equipment to provide proper student training. More than half indicate that their: schools are not adequately utilizing outside speaker programs to stimulate student interest. More than three fourths of the educators involved in research believe that their school provides insufficient release time from teaching to facilitate research. 
A similar percentage of the educators indicate that they believe that time spent searching for research funding compromises their ability to conduct research.

Greater than sixty percent of all tho rospondents believe that Montana state agencies should be actively involved in research programs. Nearly three fourths of the respondents expressed the opinion that Montana's agencies do not provide enough financial support for research. An even greater number indicated that Montana's legislative support for research is inadequate.

Over sixty percent of the respondents answered questions regarding barriers to research in Montana. Over a third of those responding indicate that they do not believe that there are significant barriers to research in Montana. However, two thirds of those responding to the barriers questions indicated that they believe that there are significant barriers to research in Montana. More than half of those indicating that barriers exist, place them at some level within their own organizations.

\section{PRELIMINARY QUESTIONNAIRE ANALYSIB}

A. Composition of the research work force:

Responses were received from the following sources and are listed in order of greatest to least number of responses:

University of Montana

Businesses

Montana State University

Montaria Tech

State Agencies

Eastern Montana College

Western Montana college 07

Community colleges

votech Schools 
General professional categories of the respondents are illustrated in the graph in FIG 1 .

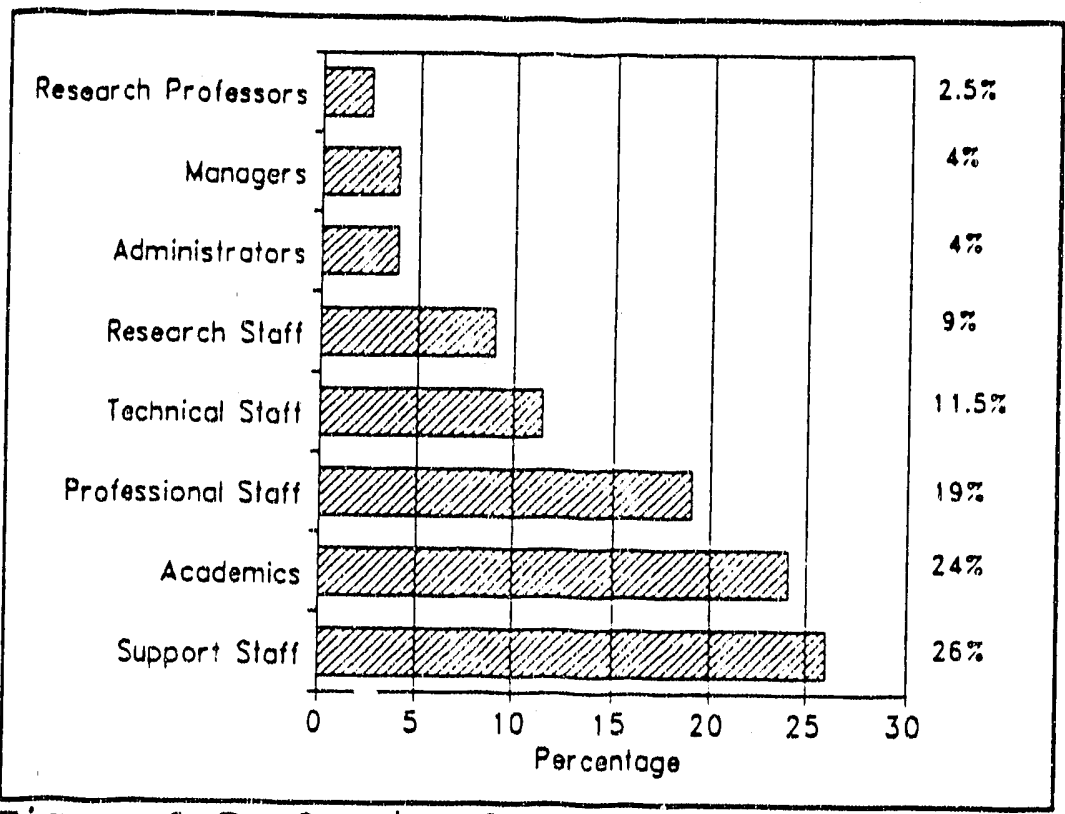

Pigure 1 Professional Categories

Respondents were also asked to select from a list the best descriptor for the type of organization that they work at. TABLE 1 illustrates total number of their choices and the equivalent percentage:

Table I Where the questionnaire respondents work

\begin{tabular}{|c|c|c|}
\hline Organizaticu & Total & Percent \\
\hline University & 43 & 35.28 \\
\hline College & 34 & $27.9 \%$ \\
\hline Consulting Firm & 10 & 8.28 \\
\hline Industry & 6 & 4.98 \\
\hline other & 6 & 4.98 \\
\hline State Agency & 5 & 4.28 \\
\hline Community college & 5 & $4.1 t$ \\
\hline Non-Profit & 4 & 3.38 \\
\hline Federal Agency & 3 & $2.5 t$ \\
\hline Private Laboratory & 1 & 0.87 \\
\hline Vocational school & 1 & 0.87 \\
\hline Tribal Agency & 1 & $0.8 t$ \\
\hline
\end{tabular}


Respondents were asked to identify their work areas and those of other employees within their immediate work group. The "top" dozen work areas they listed are illustrated in FIG 2 on the basis of percent frequency.

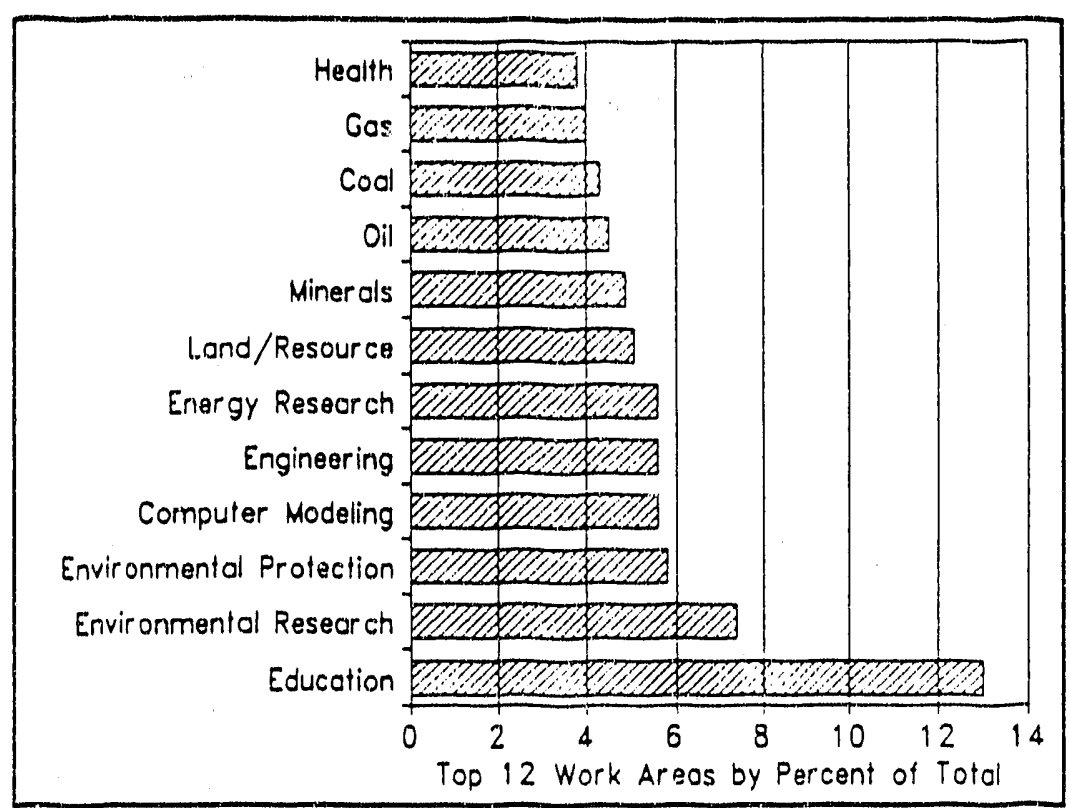

Figure 2 Top 12 work areas indicated by respondents

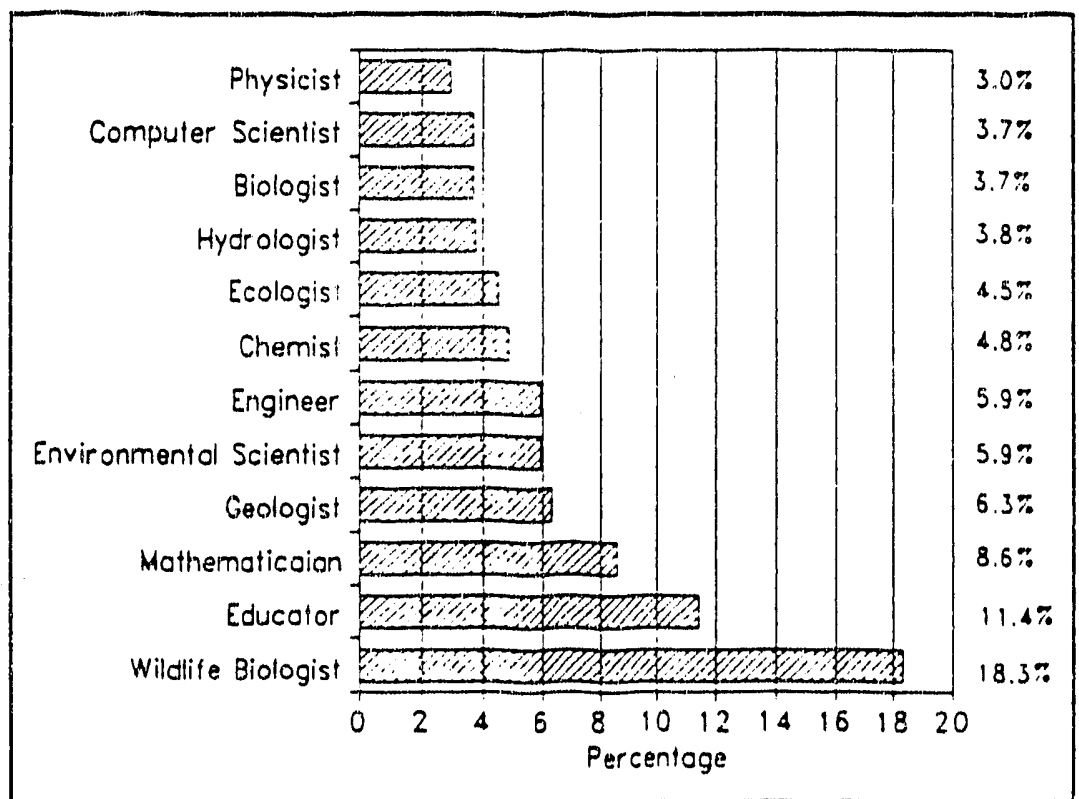

Figure 3 Most frequent profe sions listed by respondents
Respondents were asked to indicate the numbers of employees within their work group by profession. FIG 3 illustrates their responses for the "top" dozen professions that they listed. 
Respondents were asked to list the number and highest educational level

of employees

within

immediate work group. The results are illustrated in FIG 4 .

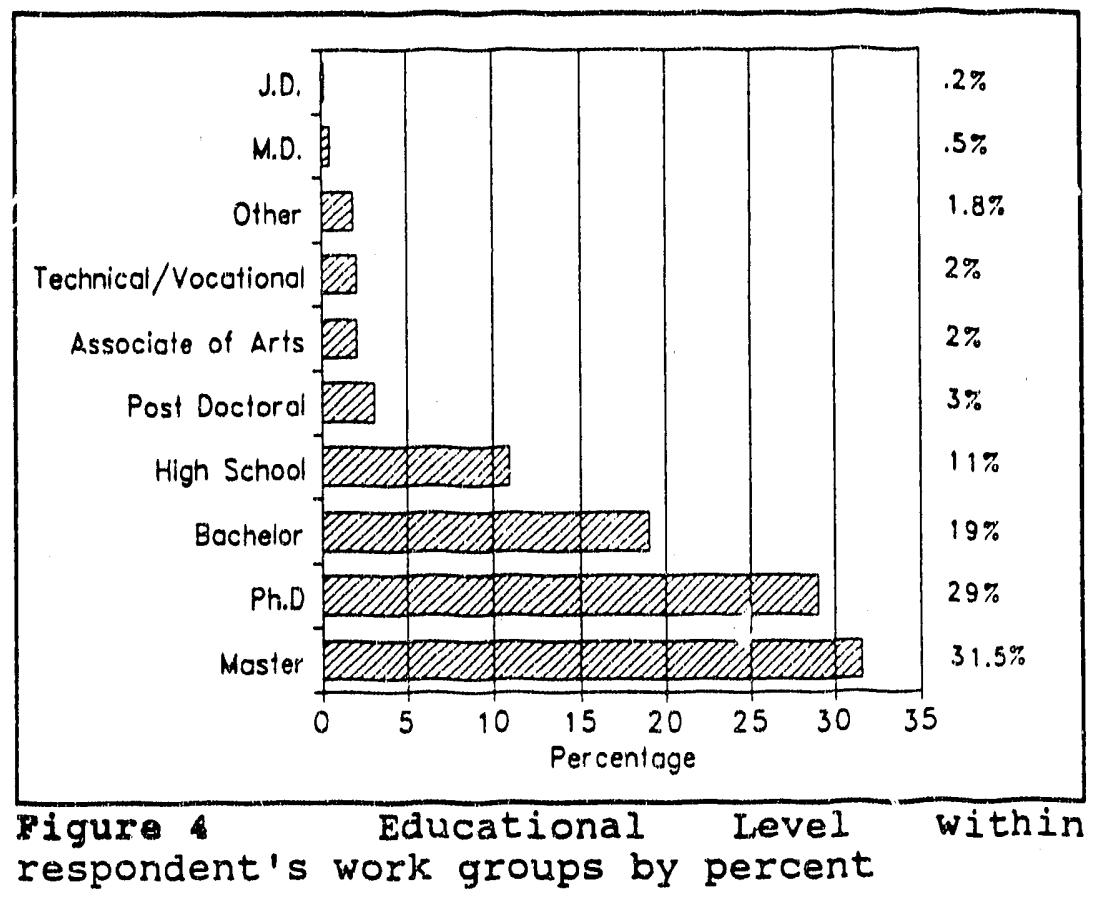

Educational Level
respondent's work groups by percent

Ethnic and racial makeup of the respondent group is 918 Caucasian, 5\% Asian, with the remaining $4 \%$ being comprised of the remaining groups.

\section{B. Funding sources:}

other demographic information sought includes the sources and amounts of research/education funding received by the participants in the survey. Respondents were asked to identify and Iist the dollar amounts of funding received over the last three years. Funding from all acknowledged sources is found in tables II and III on the following pages: 
Table 2:

Federal Bources of Montana Research Funding*

\begin{tabular}{|c|c|c|c|c|}
\hline Bourec & 2989 sotal & 1990 20tad & 2991 gotal & $\begin{array}{l}\text { Avarage } \\
\text { per year }\end{array}$ \\
\hline $\begin{array}{l}\text { Buroau of } \\
\text { Land } \\
\text { Management }\end{array}$ & $\$ 70,000$ & $\$ 45,000$ & $\$ 60,000$ & $\$ 58,000$ \\
\hline $\begin{array}{l}\text { Department } \\
\text { of Defenge }\end{array}$ & $\$ 1,000,000$ & $\$ 1,000,000$ & $\$ 1,020,000$ & $\$ 1,006,6 \cup 6$ \\
\hline $\begin{array}{c}\text { Department } \\
\text { of } \\
\text { Education }\end{array}$ & $\$ 15,000$ & $\$ 12,000$ & $\$ 12,000$ & $\$ 13,000$ \\
\hline $\begin{array}{l}\text { Department } \\
\text { of Energy }\end{array}$ & $\$ 3,405,000$ & $\$ 3,953,000$ & $\$ 14,875,000$ & $\$ 7,411,000$ \\
\hline $\begin{array}{l}\text { Department } \\
\text { of The } \\
\text { Interjor }\end{array}$ & $\$ 385,000$ & $\$ 425,000$ & $\$ 590,000$ & $\$ 466,667$ \\
\hline $\begin{array}{l}\text { Department } \\
\text { of } \\
\text { Transport- } \\
\text { ation }\end{array}$ & & $\$ 8,000$ & $\$ 2,000$ & $\$ 3,333$ \\
\hline E.P.A. & $\$ 1,160,000$ & $\$ 1, \$ 90,000$ & $\$ 1,000,000$ & $\$ 1,216,667$ \\
\hline $\begin{array}{l}\text { Eealth and } \\
\text { Euman } \\
\text { Bervices }\end{array}$ & $\$ 150,000$ & $\$ 180,000$ & $\$ 210,000$ & $\$ 180,000$ \\
\hline N.A. B.A. & $\$ 50,000$ & $\$ 1,000,000$ & $\$ 20,000$ & $\$ 356,666$ \\
\hline $\begin{array}{l}\text { National } \\
\text { Institute } \\
\text { of Health }\end{array}$ & $\$ 112,000$ & $\$ 244,000$ & $\$ 143,000$ & $\$ 133,000$ \\
\hline $\begin{array}{l}\text { National } \\
\text { sciance } \\
\text { Foundation }\end{array}$ & $\$ 394,000$ & $\$ 746,000$ & $\$ 9,390,000$ & $\$ 3,510,000$ \\
\hline $\begin{array}{l}\text { Department } \\
\text { of } 1 \pm \mathrm{sh} \\
\text { Tildife }\end{array}$ & $\$ 410,000$ & $\$ 410,000$ & $\$ 470,000$ & $\$ 430,000$ \\
\hline $\begin{array}{l}\text { Porest } \\
\text { Bervice }\end{array}$ & $\$ 120,000$ & $\$ 130,000$ & $\$ 153,000$ & $\$ 134,333$ \\
\hline
\end{tabular}


Table 3:

Non-Federal Funding Bources For Montana Research*

\begin{tabular}{|l|c|c|c|c|}
\hline Bource & 1989 & 1990 & 1991 & $\begin{array}{c}\text { Yearly } \\
\text { Average }\end{array}$ \\
\hline $\begin{array}{l}\text { Foundat- } \\
\text { Ions }\end{array}$ & $\$ 117,000$ & $\$ 198,000$ & $\$ 508,000$ & $\$ 274,333$ \\
\hline $\begin{array}{l}\text { Private } \\
\text { Industry }\end{array}$ & $\$ 220,000$ & $\$ 33,000$ & $\$ 168,000$ & $\$ 140,333$ \\
\hline $\begin{array}{l}\text { Bpecial } \\
\text { Interest } \\
\text { Groups }\end{array}$ & $\$ 93,000$ & $\$ 162,500$ & $\$ 60,000$ & $\$ 105,167$ \\
\hline $\begin{array}{l}\text { Btate } \\
\text { Goverdinent }\end{array}$ & $\$ 88,000$ & $\$ 1,009,000$ & $\$ 1,301,000$ & $\$ 1,066,000$ \\
\hline $\begin{array}{l}\text { other } \\
\text { Sources }\end{array}$ & $\$ 26,000$ & $\$ 60,000$ & $\$ 119,357$ & $\$ 68,452$ \\
\hline $\begin{array}{l}\text { Internal } \\
\text { Budgeting }\end{array}$ & $\$ 2,352,101$ & $\$ 3,407,000$ & $\$ 14,931,500$ & $\$ 6,896,867$ \\
\hline $\begin{array}{l}\text { Reflects only those amounts indicated by those } \\
\text { survey }\end{array}$ & responding to \\
\hline
\end{tabular}

C. Barriers to Research:

The respondents were queried as to whether or not they believe barriers to research exist. If they indicated barriers exist, they were asked to select from a given list of barriers. $65 \%$ of all the respondents answered the set of two questions regarding barriers to research in Montana. $33.3 \%$ of those responding indicated that they do not believe that there are significant barriers to research in Montana. However, $66.7 \%$ of those responding to the questions indicate that they believe

Table "Barriers" to Research Table A 4 Barriers" to Research

"Barriers to Research"
\begin{tabular}{|l|c|}
\hline Other & $5.4 \%$ \\
\hline Department & $8.9 \%$ \\
\hline Federal & $10.7 \%$ \\
\hline State Government & $21.4 \%$ \\
\hline Within Organization & $53.6 \%$ \\
\hline
\end{tabular}

that there are significant barriers to research in Montana. Table 4 illustrates where they believe the barriers exist. 
D. Attitudes Regarding Researcb:

over $70 \%$ of the respondents believe that interest in research has increased at their organization during the last few years. Nearly 30 indicated that they believe that quantity is placed ahead of quality. over $37 \%$ indicate discontent with their organizations' system for evaluating research productivity. An overwhelming $83 \%$ of the respondents feel that pay is lower at their organization than at peer organizations. Over $34 \%$ are dissatisfied with their systems of locating grant sources. $58 \%$ of the respondents do not consider "overhead" costs to be a hindrance to competing for research furds.

E. Bpecialized training, collaboration and communication:

$38 \%$ of the respondents indicate that their organization must invest signilicant resources for additional training for Montana graduates. An impressive $69 \%$ indicate that student traineeships and/or internships would benefit researchers. $45 \%$ of the respondents indicate that their work group is communicating well with research organizations, while $41 \%$ disagree. Over $50 \%$ of the respondents indicate satisfaction with the preparation students of Montana's university system receive, while over $36 \%$ are dissatisfied. In excess of $57 \%$ believe that Montana's university system provides nationally competitive preparation in engineering, math and science; $24 \%$ challenge that view.

\section{F. Attitudes of Educators:}

$65 \%$ of educators responding to the questionnaire indicate that their schools do not have adequate laboratory equipment to provide proper student training. Over $53 \%$ of the educators indicate that their schools are not promoting student interest through outside speaker programs. In excess of $76 \%$ of the educators indicate that their school does not provide sufficient release time from teaching to facilitate research. $66 \%$ expressed interest in learning about the education/training needs of businesses. Over $64 \%$ of the educators indicate that searching for research funding compromises their research.

G. State Role in Research:

61 of the respondents believe that Montana state agencies should be actively involved in research programs. $74 \%$ indicate that Montana's agencies do not provide enough financial support for research. Similarly, over $79 \%$ of the respondents are dissatisfied with Montana's legislative support for research. 
B. Responses to a supplied Ilat of 1tems for improving resarch: The following list of suggestions for improving research productivity appeared on the questionnaire. The percentage responses to each item on the list are tabulated to the right of each item:

increased financial incentives..................

more gradute students $\ldots \ldots \ldots \ldots \ldots \ldots \ldots \ldots \ldots \ldots . . \ldots .18$

Indirect cost ("overbead") recovery support .....8.58 improved information technologies 6 computar

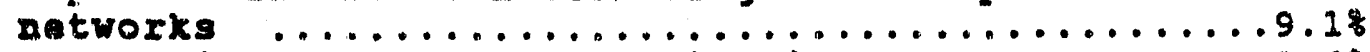

better interpersonal comminications $\ldots \ldots \ldots \ldots . . .62 .6 \%$

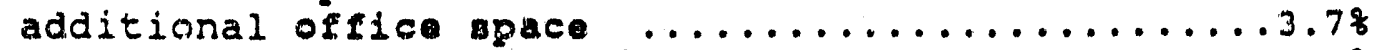

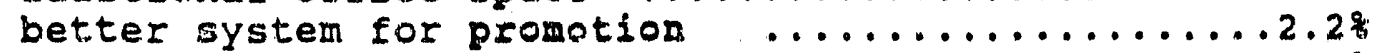

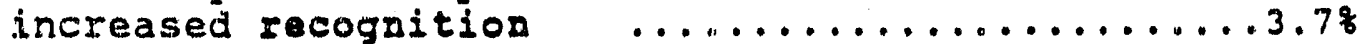

increased reforence sources .................68

additional researcb quipment ..................

additional research pace $\quad \ldots \ldots \ldots \ldots \ldots \ldots \ldots . \ldots . \ldots . \ldots .78$

changes in royalties, licenses patent policies $.0 .4 \%$

meed money for initiation of research $\ldots \ldots \ldots \ldots 12.8 \%$

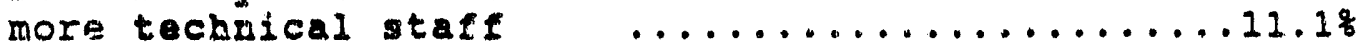

I. specialized Research Equipment:

As an aid in determining research capability, the respondents were asked to indicate the types and numbers of specialized research equipment available in their labs. The following list tabulates their responses:

3 Auger spectroscopy units

- Automated Sample preparation apparatus

15 Chromatography, Gas

10 Chromatography, Liguid

27 Computer Work Stations

1 Dielectric Apparatus

1 Electron Paramagnetic Resonance

- FIA Environmental Analyzers

13 Filtration Apparatus systems

8 Freezers (uItra-cold)

6 Geographical Information systems

3 light scattering apparatus units

10 Mainframe Computers

4 Materials Mechanical Test Apparatus systems

5 Microscopy, Electron

18 Microscopy, Light

5 Microwave Digestion Ovens

8 Nuclear Magnetic Resonance (NMR) systems

3 Particle Size Analyzers

* Remote sensing units

4 Scaming Electron Microscopes

1 Scanning Tunneling Microscope

11 spectrophotometers, $A A$

5 spectrophotometers, GC-Mass 
Ipecialized Research Equipment: continued

5 spectrophotometers, ICR

11 spectrophotometers, IR

2 Spectrophotometers, Mobile Mass

15 Spectrophotometers, UV-VIS

1 Supercritical Fluid Extraction Apparatus

- Superconductivity Apparatus

4 TCLP Equipment

3 Titrators

1 vox Analyzers 

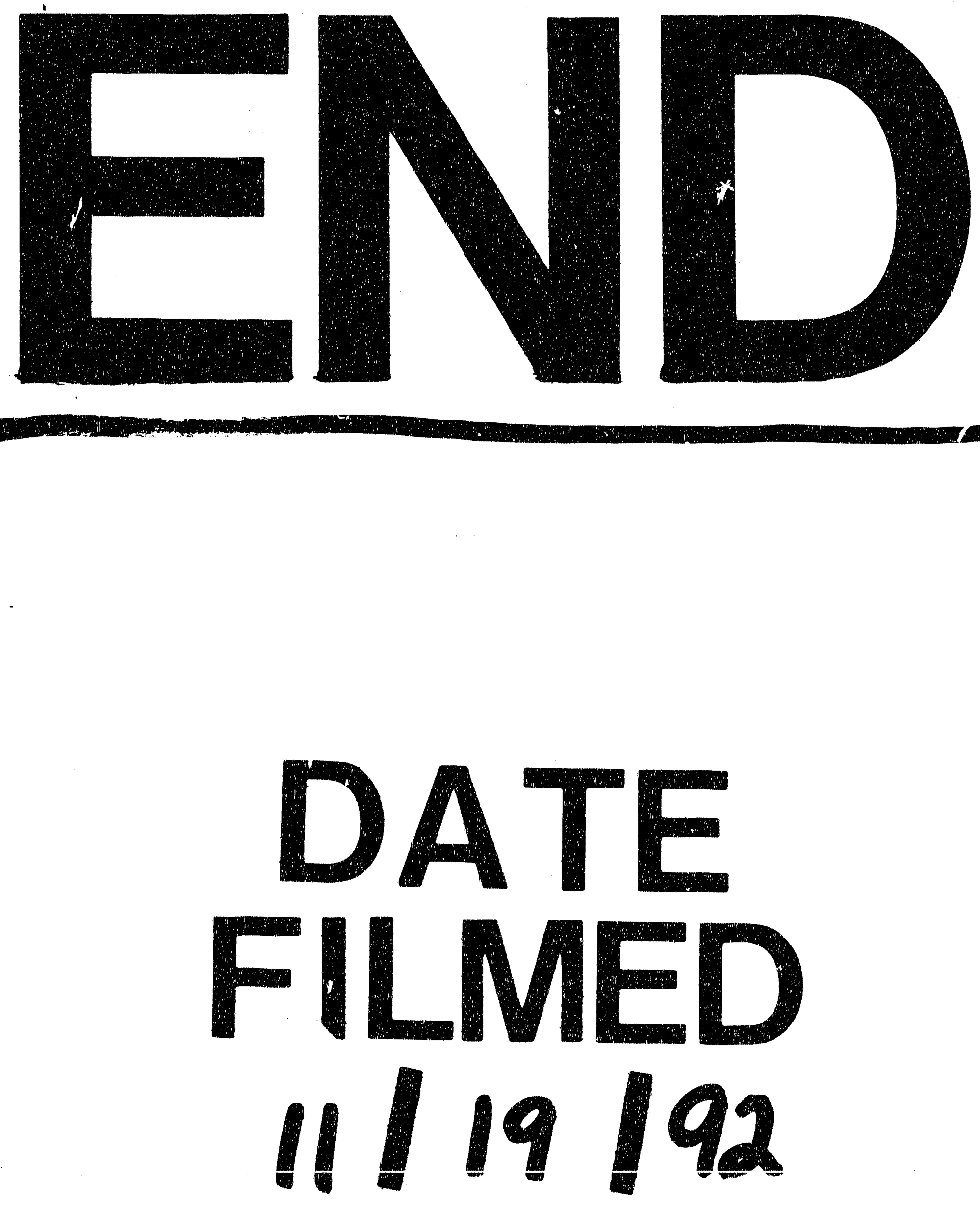


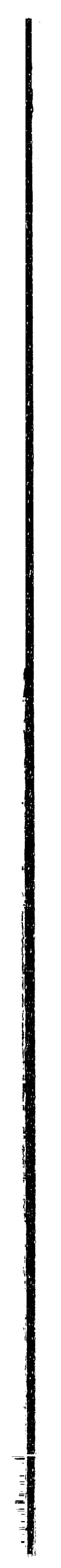

